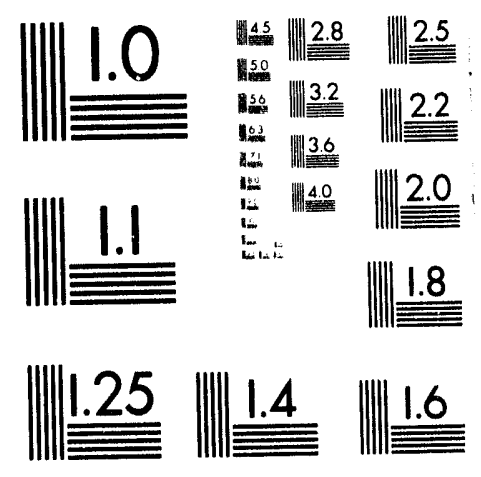



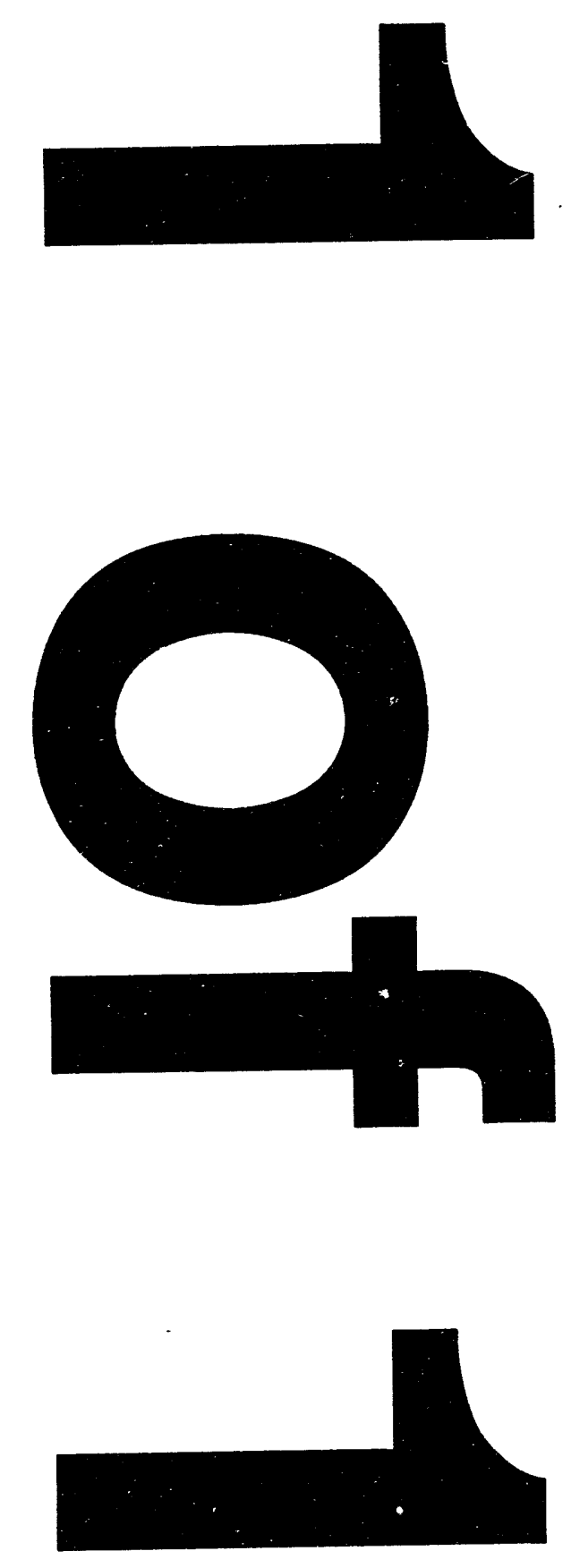


\section{Identification of Research Relating to the Critical Loads Concept and Its Potential Application to the Regulation of Acidic Deposition}

by $N$. Bhatti

Policy and Economic Analysis Group, Decision and Information Sciences Division,

Argonne National Laboratory, 9700 South Cass Avenue, Argonne, Illinois 60439

December 1993

Work sponsored by United States Department of Energy, Assistant Secretary for Policy, Planning and Program Evaluation, Office of Environmental Analysis 


\section{CONTENTS}

ACKNOWLEDGMENTS $\ldots \ldots \ldots \ldots \ldots \ldots \ldots \ldots \ldots \ldots \ldots \ldots \ldots$

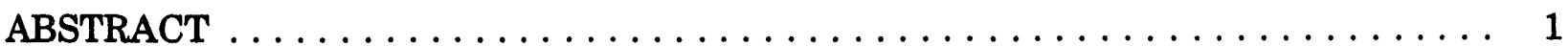

1 INTRODUCTION AND OVERVIEW $\ldots \ldots \ldots \ldots \ldots \ldots \ldots \ldots \ldots \ldots$

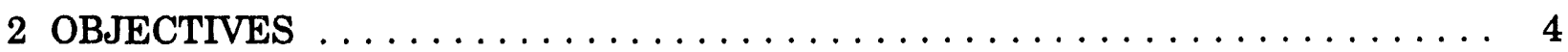

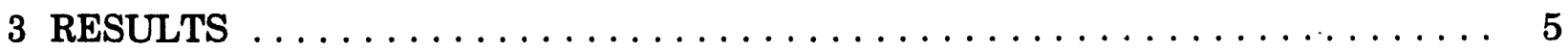

4 SUMMARIES OF SELECTED ARTICLES $\ldots \ldots \ldots \ldots \ldots \ldots \ldots$

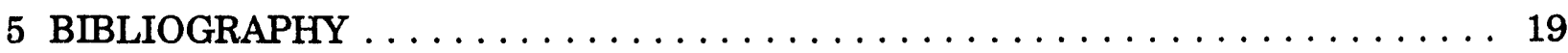

FIGURES

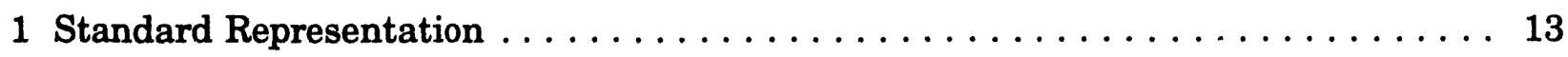

2 Nonconvexity Representation . . . . . . . . . . . . . . . . . 14 


\section{ACKNOWLEDGMENTS}

This work was conducted for the Office of Environmental Analysis in the U.S. Department of Energy. I would especially like to acknowledge the sponsorship and guidance of Roger Morris and Ted Williams. In addition, I wish to thank David Streets, Eric Maloney, and Mark Fernau of the Decision and Information Sciences Division, Argonne National Laboratory, for their assistance in this work. 


\title{
IDENTIFICATION OF RESEARCH RELATING TO THE CRITICAL LOADS CONCEPT AND ITS POTENTLAL APPLICATION TO THE REGULATION OF ACIDIC DEPOSITION
}

\author{
by
}

N. Bhatti

\begin{abstract}
The overwhelming majority of strategies currently implemented to regulate acidic deposition have focused on source-based or emission-control techniques. In the past few years, however, the fact that such source-based strategies may not be sufficient to prevent adverse ecological effects and may therefore need to be supplemented with other control options, such as receptor-based strategies, has become apparent. Partly in response to this insufficiency of regulatory controls, the U.S. Congress has required the National Acid Precipitation Assessment Program to determine (1) what deposition levels are needed to prevent such ecological damage, (2) whether such safe deposition levels (i.e., critical loads) can realistically be identified, and (3) what the costs and benefits of attaining such deposition levels are. This report reviews and culls the existing research on these alternative control strategies, emphasizing the critical loads concept, to determine the advantages and limitations and the cost-benefit relationships associated with receptor-based control options. The results of this study indicate that in spite of the significant limitations associated with the critical loads concept, this strategy dominates all discussions of non-source-based control options and offers considerable advantages, including cost-effectiveness, over the more traditional source-based control methods. Summaries of 10 of the most relevant studies dealing with alternative control strategies and the costs and benefits associated with them are also presented in this report.
\end{abstract}

\section{IN'RRODUCTION AND OVERVIEW}

To date, most of the efforts dealing with the potential threat posed by acidic deposition have focused on reducing emissions of the precursors that result in its formation (namely sulfur and nitrogen oxides) by a specified amount at the source. Such reductions have formed the basis of the Title IV provisions of the 1990 Clean Air Act Amendments (CAAA) and of various European and Canadian regulations designed to control acidic deposition. However, it is becoming apparent that if the objective of such regulations is to reduce the threat of acidic deposition to natural ecosystems and man-made structures, these 
source-based emission reduction strategies may need to be supplemented with other approaches to achieve this objective efficiently and cost-effectively.

This addition of approaches is particularly relevant with respect to the emissionstrading provisions of the 1990 CAAA, which do not make any link between sources of acidic deposition precursors and the location at which these emissions are likely to be deposited and cause damage to sensitive receptors. The concern over the absence of such a connection is evidenced by the fact that the state of New York, various electric utilities, and a number of environmental groups have filed a suit against the U.S. Envirorımental Protection Agency (EPA) to make changes in the 1990 CAAA rules. One of these changes involves attempting to force the EPA to establish a "deposition standard" that would restrict emission trading (Utility Environment Report 1993).

Congress has requested that the EPA conduct a study to determine whether such a deposition standard should indeed be implemented. Under Section 404 of Title IV, any deposition standard implemented in the future is contingent on an EPA determination that the standard is feasible, cost-effective, and indeed necessary to protect ecosystems. However, such a study has not yet been completed and thus has not met the fall 1993 deadline set by Congress.

The determination of the need for implementing a deposition standard (and the quantitative value of this standard) requires, in large part, an assessment by the National Acid Precipitation Assessment Program (NAPAP) of (1) what reductions in deposition rates are required to prevent adverse ecological effects and (2) what the costs and benefits achieved through implementation of Title IV of the 1990 CAAA are likely to be.

This assessment necessitates a shift in focus from source-based control strategies to receptor- or target-based control strategies. These receptor-based strategies attempt to link the spatial distribution of sources with those of the receptors (along with the sensitivity of the latter). This link is usually made through the use of models that account for atmospheric transport and transformation processes. Almost all these receptor-based strategies are based on the critical loads concept.

The critical load for acidic deposition (or any other po!lutant) of a given system is usually defined as the highest amount of sulfur and nitrogen (or other pollutant) that can be introduced without causing chemical and/or biological changes leading to long-term harmful effects on the system. Since ecosystems consist of numerous components, each with different levels of tolerance to acidity, the critical load is often applied to the most sensitive receptor in the system. Generally, the critical load, a scientifically based concept, is dependent on the inherent physical, chemical, and biological properties of the system in question. With regard to acidic deposition, the critical loads are usually based on the premise that inputs of acidity should not exceed the production of alkalinity within the ecosystem (Gringal 1991) and generally involve dose-response relationships (Bull 1991; Kamari et al. 1993).

Because of improved research methods and increased knowledge of the structure and function of ecosystems, critical load values have become progressively lower. This result 
introduces the question of whether the critical loads concept (or the threshold of adverse effects concept) is based on valid scientific properties of natural phenomena or whether it is simply an artifact of increases in the sensitivity of effects detection measurements (i.e., whether there is an actual deposition level at which damage begins or whether damage occurs along a continuum).

The use of the critical loads concept in regulatory decision making is the most advanced in Europe and in Canada (where the critical loads concept is believed to have originated). Although inputs of all acidic substances should be considered in determining acidic deposition critical loads for a given ecosystem, most of the existing research has focused on critical values for sulfur deposition. Setting critical loads for nitrogen compounds is much more complex and still under consideration. Thus, most values for critical loads involve only the sulfur species. The use of the critical loads concept in the regulation of acidic deposition also requires the existence of accurate source-receptor models.

Another related concept - the target load - has frequently been used in recent years. Determination of target loads involves the consideration not only of the critical load of a given system but also of other, nonscientific aspects such as economics, political objectives, and technical feasibility. The target load concept can be used to overcome the inherent incompatibility between the critical loads concept, which implies that a certain level of protection is required (level at which no damage exists) regardless of the cost involved in attaining such protection, and the cost-benefit approach, which implies that optimum controls are achieved once the costs of additional controls exceed the benefits attained from such controls. Thus, the cost-benefit approach indicates that some level of damage is acceptable. 


\section{OBJECTIVES}

The main objective of this project was to review and cull the existing research on the various strategies, particularly receptor-based strategies, that could be utilized to prevent advcrse effects expected from continued acidic deposition in the United States. Emphasis was placed on the limitations and strengths of the critical loads concept and the cost-benefit relationships associated with its use. 


\section{RESULTS}

A main conclusion reached through the review of current literature on the regulatory alternatives for control of acidic deposition is that the critical load concept dominates all discussions of receptor-based strategies. Only a few of the papers reviewed in this search discussed alternative strategies for reducing acidic deposition (sulfur deposition in this case), and even those papers were ultimately based on the critical load or threshold of damage concept in some form or another.

Another conclusion reached through this review is that little agreement exists on the values of critical loads for individual ecosystems, particularly in North America. This lack of agreement results from the deficiency of comprehensive research on this topic in North America, the considerable variability in the sensitivity of ecosystems to acidity in Canada and the United States, and the presence of a variety of pollutants (especially nitrogen compounds) that can add to deposition acidity.

Although critical loads vary with the system being studied, it is generally accepted that a deposition limit of $20 \mathrm{keq} \mathrm{H} / \mathrm{km}^{2} / \mathrm{yr}(3.2 \mathrm{~kg} \mathrm{~S} / \mathrm{ha} / \mathrm{yr}$ if all acidity results from sulfur) would protect the majority of ecosystems in Europe (Hettelingh et al. 1991b; Kuylenstierna and Chadwick 1988). At a Nordic Council of Ministers meeting in 1986, it was determined that the critical load for total sulfur for soils and lakes in Norway and Sweden was between 12 and $45 \mathrm{keq} \mathrm{SO}{ }_{4}{ }^{2-} / \mathrm{km}^{2} / \mathrm{yr}$ ( 2 and $7 \mathrm{~kg} / \mathrm{ha} / \mathrm{yr}$ ) (Nilsson 1986). In general, critical loads for sulfur in the European region range between 0 and $200 \mathrm{keq} / \mathrm{km}^{2} / \mathrm{yr}$ (Hettelingh et al. 1991a). Sulfur deposition levels in Europe currently average from $3 \mathrm{~kg} / \mathrm{ha} / \mathrm{yr}$ in the far northern reaches of Scandinavia to $20-30 \mathrm{~kg} / \mathrm{ha} / \mathrm{yr}$ in the forest areas of southern Norway and Sweden to $40 \mathrm{~kg} / \mathrm{ha} / \mathrm{yr}$ in Central Europe (Swedish NGO Secretariat on Acid Rain 1993). Parts of Central Europe, particularly the Czech Republic and Poland, receive sulfur deposition loads as high as $100 \mathrm{~kg} / \mathrm{ha} / \mathrm{yr}$. Almost all of these loads exceed critical loads estimates for these regions.

In the intermontane region of the western United States, estimates are that total sulfur deposition rates of between 3 and $5 \mathrm{~kg} / \mathrm{ha} / \mathrm{yr}$ are required to protect the ecosystems (especially aquatic resources) of this region (Yuhnke and Oppenheimer 1984). In 1981, total sulfur deposition rates at lower elevations of this region averaged between 3.4 and $6 \mathrm{~kg} / \mathrm{ha} / \mathrm{yr}$. At higher elevations, where the more sensitive ecosystems are located, sulfur deposition loads are likely to be higher.

In the northeastern United States, Henriksen and Brakke (1988) determined that critical loads for wet sulfate for these ecosystems were between 9 and $17 \mathrm{~kg} / \mathrm{ha} / \mathrm{yr}$. Wet sulfate deposition for this region between 1985 and 1987 averaged from 12 to $32 \mathrm{~kg} / \mathrm{ha} / \mathrm{yr}$ (Shaffer et al. 1991).

In the 1983 Memorandum of Intent, Canadian members stated that deposition of wet sulfate should be reduced to $20 \mathrm{~kg} / \mathrm{ha} / \mathrm{yr}$ to protect all but the most sensitive aquatic ecosystems in Canada (Milburn-Hopwood and Puckett 1992). This target load value became 
the basis for the Canadian acid rain control program. It was later realized that reduction of wet sulfate deposition to a load of $12 \mathrm{~kg} / \mathrm{ha} / \mathrm{yr}$ was necessary to ensure that no further loss of sensitive lakes occurred and that recovery of recently acidified lakes could begin (RMCC 1986). Maximum sulfur deposition loads observed in the early 1980s in eastern Canada were approximately $40 \mathrm{~kg} / \mathrm{ha} / \mathrm{yr}$.

More recent studies in Canada have revealed that critical loads for wet sulfate deposition to aquatic systems vary from less than $8 \mathrm{~kg} / \mathrm{ha} / \mathrm{yr}\left(17 \mathrm{keq} / \mathrm{km}^{2} / \mathrm{yr}\right)$ to more than $20 \mathrm{~kg} / \mathrm{ha} / \mathrm{yr}$ (42 keq/ $\mathrm{km}^{2} / \mathrm{yr}$ ), depending on site characteristics (RMCC 1990).

The above discussion of critical loads and deposition levels demonstrates that current loads of acidic substances (particularly sulfur species) exceed critical loads for many ecosystems in Europe and North America. However, considerable controversy currently exists on what the value of the critical load is for any given region and whether and how changes in air quality regulations would affect deposition levels.

All of these controversies and conclusions indicate that the significant limitations associated with the critical loads concept make it difficult to use this concept as a basis for regulatory control of acidic deposition. These limitations, and the sources that discuss them, include the following:

- The critical loads concept assumes that ecosystems respond in an all-ornothing fashion to acidic deposition (i.e., threshold of adverse effects). In reality, a gradual deterioration of environmental quality with increasing departures from optimal $\mathrm{pH}$ is possible (Batterman 1992; Newcombe 1993; Chadwick and Kuylenstierna 1989). It also is plausible that no level of exposure to acidic deposition is entirely free of adverse effects (Gringal 1991).

- The critical load value depends on the definition of harmful effect (Bull 1991; Hettelingh et al. 1992a), and agreement is unlikely on what constitutes definitive damage to an ecosystem. This lack of agreement is especially true, considering the limitation expressed above. For example, Kamari (1989) states that there is a "gradual deterioration of surface water ecosystems with the successive process of acidification. Therefore, the criteria for what might be considered harmful is largely a matter of subjective decision."

- The critical load value depends on the choice of the most sensitive/valuable receptor (Hettelingh et al. 1992a; Holdren et al. 1993c). This choice is likely to be controversial.

- Critical load values are not static for any given receptor but can change with changes in land-use patterns, inputs of other pollutants, climate parameters, and other, non-acidity-related factors (Waters and Whitehead 1992; Streets et al. 1985; Posch et al. 1993). For example, if 
nitrogen loading to a given ecosystem increases, the critical load for sulfur decreases (de Vries and Gregor 1991). Thus, the total pollutant mixture received by an ecosystem should be known before the critical load for a given pollutant can be calculated.

- The value of the critical load for any given system depends on the models, data sets, and assumptions used (Shaffer et al. 1991). Thus, considerable variability in critical loads for a single receptor can exist. One of the goals of the U.S. critical loads project is to assess the effects of different assumptions used to develop critical load values for various ecosystems. It is becoming evident that no single method is likely to be accurate in estimating critical loads for all ecosystems in all areas (Holdren et al. 1992).

- Cost-effective strategies utilizing the critical loads concept concentrate reduction efforts on sources that cause the greatest deposition on sensitive receptors (Shaw 1986a). This focus results in unequal emissions reductions that would not be politically palatable unless costsharing measures were also included.

- The critical load parameter is a steady-state, static variable that is being used to assess the response of a dynamic system. As such, the critical load concept does not account for lag effects, changed equilibrium states, or chronic, accumulative effects (Chadwick and Kuylenstierna 1989; Gringal 1991).

- The critical load for a given forest ecosystem (or lake watershed area) is usually determined through an evaluation of the chemical weathering rate of base cations in the soil. However, even if the load of acidic substances is below the weathering rate (and thus below the critical load), the ecosystem could possibly be adversely affected as a result of nutrient imbalances (de Vries and Gregor 1991). Taking these nutrient imbalances into account would require an evaluation of each individual ecosystem and its constituent species.

- In some soils (e.g., podzols), the proton (acid) load associated with natural soil-forming processes already exceeds the chemical weathering rate of these soils. Additional acidity will not affect base cation levels in this case. Thus, the objective of maintaining constant base cation levels (as is the objective in establishing critical load values) is not very relevant in these soils (de Vries and Gregor 1991), which are common in the northeastern United States and Canada.

- Background deposition in some areas may be so high that it is above calculated critical loads. This situation causes extreme difficulty in devising effective receptor-based regulatory strategies (Hicks et al. 1993; 
Amann 1989). The approach adopted by the Canadians to overcome this problem is to use, as the operational definition of critical loads, the highest sulfate deposition that does not increase the percentage of ecosystems (lakes in this case) with $\mathrm{pH}$ values below the critical or threshold level (RMCC 1990a,b).

- Application of the critical load concept to the regulation of emissions assumes the existence of accurate, realistic atmospheric transfer models (Smith 1992; Batterman and Amann 1991). Haigh (1989) stated that even if scientifically sound critical loads were available for all ecosystems, it would be difficult to apportion, with any degree of confidence, deposition levels back to the individual sources contributing to this deposition load. In addition, the spatial resolution of deposition and critical loads is different; deposition is generally managed on a regional scale, whereas critical loads are determined on a site-specific basis (Holdren et al. 1993c). Thus, site-specific changes in deposition (needed to protect ecosystems) cannot be accomplished easily (Crocker and Regens 1985).

- A reference condition is nceded to estimate critical loads. For example, is the basis of the critical load to restore the ecosystem to its pristine state (if indeed such a state can be identified) or is it to prevent further deterioration (Hunsaker et al. 1993)?

One method available for overcoming some of the limitations associated with the critical loads concept as outlined is to use an alternative definition of critical loads. Persson (1988) has defined the critical load as that level of pollutant deposition that is within the limits compatible with sustainable development. This definition provides a specific objective to be achieved through limiting deposition below a certain level and accounts for the deposition of different mixtures of pollutants. Its value, however, would vary considerably among different ecosystems.

A different receptor-based approach to dealing with the acidic deposition issue was also discovered through this literature search. A paper by Hettelingh et al. (1992b) advocated that abatement policies should not be established simply by setting deposition loads lower than or equal to critical loads, but rather by basing these loads on spatial heterogeneity and time-dependent changes in critical values of soil and water chemistry. What this strategy entails is taking the control step beyond critical loads to the basic chemical and biological indicators of ecosystem health. Critical loads are generally determined on the basis of these indicators, and even this more novel approach is related to the critical loads concept.

Given the various problems and limitations associated with the critical loads concept, some researchers have concluded that the use of target loads (based on a best judgment of ecosystem sensitivity and political/economic realities) is advisable in devising control strategies for acidic deposition, but that not enough information is currently available to devise accurate target load values (Milburn-Hopwood and Puckett 1992). 
In addition, considerable controversy is associated with the determination of target loads for acidic deposition, particularly related to the cost-effectiveness of reducing acidic deposition concentrations below a given level. This uncertainty stems largely from the uniqueness of the nature of ecosystem damage attributable to acidic deposition. Conventional cost-benefit analysis associated with environmental issues involves the use of standard doseresponse relationships that assume that ecosystem damage increases monotonically with increasing acid inputs. Acidic deposition, because of the nonconvexity and irreversible nature of many of the types of damage associated with it, does not conform to this traditional doseresponse relationship. (See the summary of the paper by Crocker et al. [1980] in the next section for a more detailed discussion of this topic.) These properties of the acidic deposition phenomenon also complicate the threshold of adverse effects concept related to acidic deposition.

This literature search also revealed that in spite of the limitations to the critical/target loads coicept, the receptor-based method offers considerable advantages over source-based strategies in dealing with the damage attributable to acidic deposition. Most of the source-based regulatory methods apply arbitrary emission reductions not directly related to the prevention of damage or improvement of health of a given receptor. Receptorbased control strategies, however, involve linking emissions to deposition/effect. In addition, because this concept is based on the intrinsic properties of the substrate under threat, it has a strong scientific foundation that, apart from improvements in understanding ecosystem structure and function, is difficult to dispute once the assumptions used in its determination are accounted for.

Furthermore, the use of receptor-based strategies allows more cost-effective control strategies to be implemented, since emissions reductions are concentrated in areas where such reductions are needed the most (i.e., areas containing the most sensitive receptors and/or those receiving the highest levels of acidic deposition). In general, receptor-based approaches more directly connect the cost of controlling acidic deposition to some measure of the ensuing environmental benefits (Ellis 1988).

Because receptor-based approaches can be more efficient than source-based approaches in reducing damage caused by acidic deposition, a key question is: To what objective should such efficiency be applied? The critical load objective is to result in no damage. The target load objective is an amalgam of political, economic, and damage reduction considerations. A third objective could be to achieve cost-benefit balance, wherein no preconceived load limit is imposed, but rather damage is reduced to the point at which the value of further damage reduction would be less than the cost of achieving such reduction.

An advantage of the receptor-based concept is that it enables the assessment of the total environmental resource impacts of, and thus the direct ecosystem benefits associated with, a reduction in acidic deposition. In addition, through use of critical loads and optimization procedures, it is possible to determine the cost-effectiveness of an emission control strategy as related to the environmental impact on a given receptor. Finally, critical 
loads offer a means to compare and evaluate the effectiveness of different pollution control strategies (Kuylenstierna and Chadwick 1988; Hettelingh et al. 1992a).

Ninety-two articles were found in this search of literature related to the regulation of acidic deposition. Of these, 10 papers were selected and judged to be the most relevant to the objectives of the NAPAP Interagency Committee. Priority was placed on papers that dealt with as full a spectrum of the opinions on and aspects of the receptor-based regulatory strategies as possible. Also, priority was given to papers that dealt with use of the critical loads concept in the United States and North America, cost-benefit aspects of this issue, and limitations on the use of this concept.

A summary of each of these 10 papers is presented in the next section. A bibliography of the complete set of papers obtained from this research follows these summaries. 


\section{SUMMARIES OF SELECTED ARTICLES}

Batterman, S. (1989). Selection of Receptor Sites for Optimized Acid Rain Control Strategies. Journal of Environmental Engineering 115:1046-1058.

This paper provides a general overview of the differences, advantages, and disadvantages of source versus receptor-oriented (or targeted) strategies to control pollutant emissions. The author states that receptor-based strategies, by coordinating emissions reductions in various locations and economic sectors, are likely to be more cost-effective than source-oriented approaches.

The ensuing discussion indicates that the determination of "critical receptors" is essential to an acceptable targeted emission control strategy. This paper examines how such receptors can be found for a receptor-based control strategy that aims to minimize total control costs. The process of selecting influential receptor sites for sulfur deposition is used as an example. The critical receptors in North America and Europe found in the search are then mapped. Once found, critical receptors can be used in optimization techniques. Considering only these influential sites for use in optimization models can significantly reduce computational effort and ease the burden of extensive data collection. The use of influentia! seceptors can also be beneficial in techniques involving multiple pollutants and nonlinear environmental indicators.

Bull, K. (1991). The Critical Loads/Levels Approach to Gaseous Pollutant Emission Control. Environmental Pollution 69:105-123.

This paper provides a general overview of the critical loads/levels concept. It indicates that the critical loads concept is based on a dose-response relationship, and that this assumes the existence of a threshold of adverse effects on a given receptor. However, the author explains how this concept may not be easy to apply and identifies several limitations in its use. A history of the use of this concept and the general steps involved in arriving at an agreement to map the critical loads and levels for countries in Europe and North America as a means of assessment are also provided in this paper. Recent developments indicate that the critical loads concept could be adapted to determine the effects of different pollutants and their levels and to devise control strategies to prevent or limit their effects on a variety of receptors.

Some of the attempts at quantifying critical loads and levels for different ecosystems are illustrated, with the general conclusion being that it is difficult to arrive at a single approach to estimate critical loads. In spite of this difficulty, it appears that there is broad agreement on the critical load values calculated through use of these different methods. 
Chadwick, M., and J. Kuylenstierna (1989). Critical Loads and Critical Levels for the Effects of Sulphur and Nitrogen Compounds. Stockholm Environment Institute at York, University of York, York, United Kingdom.

This paper discusses some of the most important limitations associated with use of the critical loads concept, particularly those related to the effects of sulfur and nitrogen compounds on various ecosystems. Four methods of calculating critical loads are described: empirical methods, ion budget studies, process models, and paleolimnological reconstructions. Noted is the fact that uncertainties arise in all of these approaches, resulting from their methods of calculation and the quality of the input data. Some of the questions often associated with the critical loads concept are identified in this paper, including whether acute and chronic doses should be treated differently, how doses in multiple-pollutant systems can be addressed, whether the structure or function (or both) of a given ecosystem should be considered, and what represents a satisfactory measure of response in complex systems.

This paper discusses how mapping of the critical loads and relative sensitivity of ecosystems can be accompiished after calculations of critical-load-related values have been made. The relative sensitivity of ecosystems can be mapped over a large region by using relatively few factors, such as rock type, soil type, land use, and mean annual rainfall.

The authors stress that although both sulfur and nitrogen compounds contribute to acidification, the contribution of nitrogen to acidification is more difficult to determine than that of sulfur since nitrogen can act as a nutrient in ecosystems. In addition, because the effects of sulfur on vegetation vary from site to site, a successful assessment of critical loads must take into account those factors influencing plant and animal sensitivity.

Crocker, T.D., and B. Forster (1981). Decision Problems in the Control of Acid Precipitation: Nonconvexities and Irreversibilities. Journal of the Air Pollution Control Association 31:31-37.

This report discusses some of the issues involved in assessing the economic benefits of imposing controls on acidic deposition. A resource allocation process framework is developed to explain the behavior of ecosystems. This framework is then integrated into a benefit-cost analysis. Benefits of control are examined and quantified for Minnesota and the states east of the Mississippi.

The authors state that much of the debate on cust-benefit analysis of environmental problems focuses on how to calculate the economic or monetary value of the resources potentially affected by acidic deposition. The traditional cost-benefit analysis used for environmental problems involves the optimization of the costs and benefits of control measures as illustrated in Figure 1 (marginal damage [benefit] dose-response function). This dose-response function implies that compromise control measures, where some degree of harm (or damage) is permitted to obtain the benefits of pollution-generating activities, is the most economically efficient. 


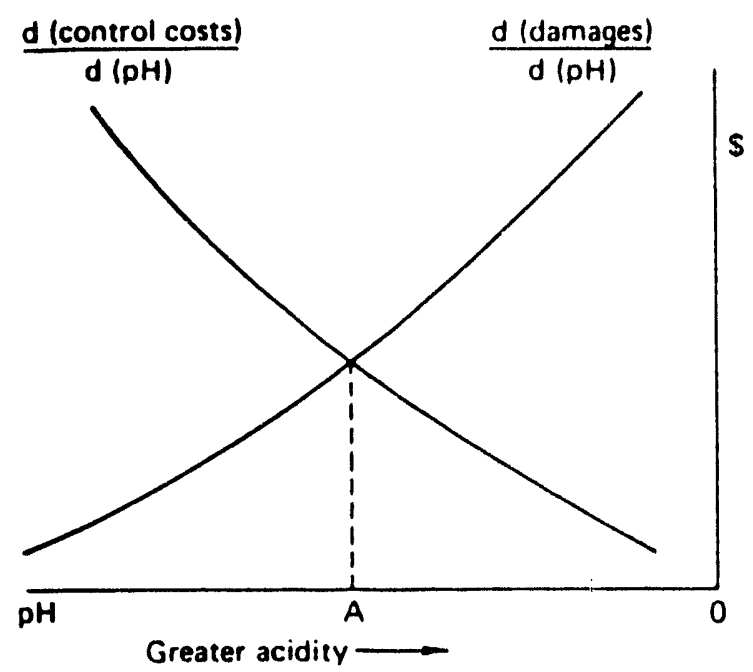

FIGURE 1 Standard Representation

However, two properties of the damage attributable to acidic deposition make it difficult to apply this traditional dose-response function to acidic deposition. These properties are related to the nonconvexities and irreversibilities of the ecosystem damage associated with acidic deposition. The authors explain these properties as follows:

- Nonconvexities. The traditional dose-response function assumes that as ecosystem acidity increases, the rate of ecosystem damage should increase monotonically. Acidic deposition damage, however, often does not follow this pattern. In many of the impacts associated with acidic deposition, particularly on aquatic ecosystems, very rapid deterioration in ecosystem health occurs as $\mathrm{pH}$ initially declines below the optimal level. This rate of ecosystem damage then decreases as $\mathrm{pH}$ levels drop further. The dose-response curve in this case would look somewhat like that in Figure 2.

This situation implies that if an ecosystem is already highly acidified, large control costs would be incurred to generate few, if any, ecosystem benefits. Only once the $\mathrm{pH}$ of the ecosystem increases beyond point $\mathrm{B}$ in Figure 2 do substantial benefits begin to ensue. Thus, decisions to control acidic deposition have strong all-or-nothing elements, since intermediate control measures result in large control costs with relatively few benefits.

- Irreversibilities. In most ecosystems, once the pH falls below a certain level, it appears that no large-scale reversals in ecosystem decline are economically or technically feasible in other than geologic time. Thus, such decline is considered irreversible. The traditional dose-response curve does not apply to these ecosystems, since there is no ecosystem response even if the dose is decreased (i.e., $\mathrm{pH}$ is increased to optimal levels). 


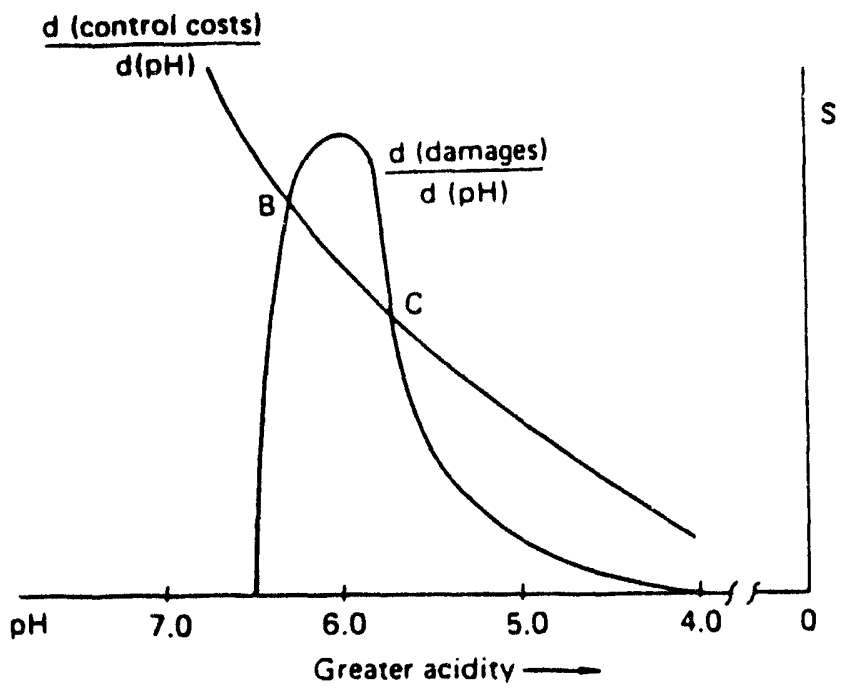

FIGURE 2 Nonconvexity Representation

Both of these properties of acidic deposition effects imply that compromise control measures could be the least desirable policy, from an economic perspective, to choose. In addition, the authors state that these properties of ecosystem damage resulting from acidic deposition indicate that greater emphasis should be placed on preventing ecosystems from moving to the right of point $B$ as shown in Figure 2, and that any activity leading to irreversible damage should be given priority in control activities. Furthermore, systems that are on the verge of acidification should be studied in greater depth to determine the shape of their dose-response functions, and those to the left of point B in Figure 2 should also be given priority in control efforts.

Gringal, D.F. (1991). The Concept of Target and Critical Loads. Electric Power Research Institute, Palo Alto, Calif.

This paper provides a history of the development of the critical/target loads concept and a summary of research conducted on this topic to 1988. Roots of the concept are traced back to a 1975 study by Woodwell, in which the idea of a threshold was introduced. Many of the subsequent proposed targets for control of acidic deposition have been based upon different interpretations of Woodwell's basic threshold concept.

The author states that one of the most influential papers in the development of a specific target load for acidic deposition is one done by Henriksen in 1979, which determined that the threshold for acidity in precipitation was between 4.6 and 4.7. Subsequent attempts at calculating target loads are detailed, and it is noted in most of these analyses that Henriksen's data and inferences have been used.

This paper also discusses the critical loads concept and its derivation for a number of different ecosystems. A history of attempts at calculating critical loads by a number of 
different researchers/workshop groups is detailed, along with the general assumptions used. The general conclusion reached through these studies is that since the characteristics of different ecosystems within a region may vary greatly, it is difficult to set a critical load for a region as a whole.

This paper also outlines a six-step process proposed by the EPA through which critical loads can be set on a regional basis, although each of the steps is associated with uncertainty and the necessity to make a variety of critical assumptions. An additional concept outlined in this paper is that of a critical emission density (as delineated in research conducted by Ulrich), which involves the quantity of emissions of a pollutant that is released per unit of land area in a given country or region. This emission density concept requires knowledge of the effects of a pollutant on an ecosystem as well as an understanding of atmospheric emissions, transport, transformations, and deposition processes to assess not only the critical loads for a given ecosystem but also the relationship between emissions and deposition.

The author concludes that the concepts of target and critical ioads require much scrutiny, especially regarding the philosophy of their establishment as thresholds and their quantitative veracity, before they are used to formulate pollution control policy.

Hettelingh, J.P., R. Gardner, and L. Hordijk (1992b). A Statistical Approach to the Regional Use of Critical Loads. Environmental Pollution 77:177-183.

This paper attempts to provide a means to improve the critical loads concept. The authors argue that the effects of abatement policies can be better evaluated by basing the success of such policies on the spatial heterogeneity and time-dependent changes in critical chemical values in soil and water chemistry rather than by simply setting deposition loads below critical loads. This can be accomplished through two approaches: (1) applying site-specific models to broad spatial scales and (2) using the results of this broad-scale approach to compute the effects on critical chemical values.

By using the Netherlands as a case study, the authors apply a five-step method of flexible zoning (MFZ) to the RAINS-Lake-Model to determine parameters that are the most important in explaining the variation in $\mathrm{pH}$ values for watersheds in the southeastern portion of the Netherlands. Different combinations of deposition levels and regional characteristics are used to better emulate the workings of a large-scale environmental system.

The results of this large-scale analysis indicate that the dynamic concept of critical chemical levels rather than the more static concept of critical loads allows for a more accurate assessment of how changes in emissions would affect ecosystems. In addition, it enables an estimation of the recovery time of an acidified ecosystem. This study also shows that a division of the receptors into "sensitive" and "insensitive" sites leads to more reliable predictions of the success of abatement strategies. 
Newcombe, C. (1993). Acid Deposition in Aquatic Ecosystems: Setting Limits Empirically. Environmental Management 9:277-288.

In this paper, the author states that although acidic deposition has the potential to harm ecosystems, the cause-and-effect relationship of this pollutant to ecosystem damage is not well understood. Because of this deficiency in knowledge, considerable controversy exists regarding how best to deal with the acidic deposition phenomenon. This paper advocates that empirical models rather than explanatory ones should be relied on to overcome this deficiency.

The report describes an empirical model that uses a three-dimensional representation that can help determine the limits of acidic deposition required for any level of protection to aquatic ecosystems. This model provides evidence for the cause-and-effect relationship between sulfur dioxide emissions and acidic deposition, which is necessary for the implementation of successful pollution control legislation. This approach can be used to identify the amount of harm caused by specific rates of acidic deposition in areas of different sensitivity.

The author indicates that there is no particular range of $\mathrm{pH}$ values within which a given aquatic ecosystem is protected and outside of which it is harmed. However, successive departures from neutral $\mathrm{pH}$ result in a gradual deterioration of environmental quality. Thus, the development of a threshold for protection of a given ecosystem is a matter of subjective evaluation. In general, the range of $\mathrm{pH}$ values deemed acceptable reflects the range that will protect the most valued aquatic resource. The empirical model accounts for this situation through its calibration ability.

The empirical model described in this paper integrates all of the major and minor variables involved in influencing the status of a water body. It generates a three-dimensional curved surface through the use of four variables: $\mathrm{pH}$ of surface waters, rate of acidic deposition, alkalinity, and the harmful effects of acidification. If the model is calibrated properly, limits to the rate of sulfate deposition can be set, above which damage to the ecosystem would occur. Calibration would involve the integration of knowledge from aquatic biology, geochemistry, meteorology, and limnology.

The report explains that such a strategy would open up lines of communication between the scientific and political communities and forge a sense of cooperation on the problem of acidic deposition.

Streets, D.G., D. Hanson, and L. Carter (1984). Targeted Strategies for Control of Acidic Deposition. Journal of the Air Pollution Control Association 34:1187-1197.

This paper examines strategies for controlling acidic deposition that maximize reductions of sulfur dioxide emissions while minimizing the costs of such a control program. Current pollution control cost and atmospheric transport models, though they may have their limitations, can provide a rough idea of the advantages and disadvantages in using different 
emission control strategies. By using these models to examine the Senate bills S.768 and S.769 (which called for massive reductions of sulfur dioxide emissions in the eastern United States), great inefficiencies are found in the bills' effectiveness for reducing sulfur deposition. When targeted strategies (strategies desifned to maximize sulfur deposition reduction in certain - usually the most sensitive - receptor areas) are utilized, the results are more promising. Using the Adirondacks as the targeted receptor site, costs can be reduced 75-90\% by using targeted strategies instead of the approaches proposed in the two Senate bills to achieve the same amount of deposition reduction.

The authors also present targeted strategies that can achieve multiple objectives such as optimal deposition reduction in a number of different receptors. Other costminimizing targeted control strategies are also considered, including the phased-in approach, in which sources nearest to sensitive receptors are controlled first, with control of progressively more distant sources following. Another strategy is to first control emissions at sources where control costs are the lowest.

The authors note that targeted control strategies are susceptible to meteorological variability. This does not, however, eliminate the cost savings of such strategies when they are compared with nonoptimized strategies. In general, the design of targeted strategies is dependent on the objectives to be achieved through emissions control (i.e., sensitive sites should be identified early). This control is often lacking.

The disadvantages of such strategies are also examined and include the fact that use of targeted strategies is dependent on accurate source-receptor models (which may not be available) and a linear relationship between emissions and deposition (which may not be realistic).

Young, J., and R. Shaw (1986). A Proposed Strategy for Reducing Sulphate Deposition in North America - I. Methodology for Minimizing Sulphur Removal. Atmospheric Environment 20:189-199.

This paper examines four schemes to reduce sulfate deposition in North America. Through use of source-receptor relationships, the source areas that produce the greatest contribution to sulfate deposition are singled out for emissions controls. The goal of all these schemes is to minimize the amount of sulfur that is required for removal at the source.

The first three schemes use a ranking method in which the receptor receiving the greatest amount of sulfate deposition would be considered first. The first strategy reduces emissions from the source with the greatest atmospheric linkage to the chosen receptor and then reduces emissions from the source with the second greatest linkage, and so on. The second strategy is similar to the first except for the fact that source strength is also taken into account. The third strategy does not reduce source emissions sequentially through a ranking system but rather reduces emissions from all sources simultaneously in amounts proportional to their respective contributions to deposition at the chosen receptor site. Once 
an acceptable deposition level for a receptor site is achieved, the receptor receiving the next highest deposition is considered.

The final scheme uses a multireceptor approach to reduce deposition at several, and sometimes all, receptor points simultaneously. The receptors are ranked two-dimensionally on the basis of their sulfate deposition. Emissions reductions, weighted by each source's total contribution to deposition, are then carried out simultaneously at all sources.

The results of the analysis contained in this paper imply that when technology limitations are not considered, emission reductions in the Ohio River Valley, northern Appalachia, the lower Great Lakes, Ontario, and Quebec would be necessary for all four schemes. However, when technology limitations are taken into account, reductions in a greater number of source areas are needed. Selection of the highest ranking sources is not affected much by meteorological variability, uncertainties within the models, and differences between the models.

Yuhnke, R., and M. Oppenheimer (1984). Safeguarding Acid-Sensitive Waters in the Intermountain West: A Sulfur Pollution Strategy for Preventing Damage in the Intermountain Air Shed. Environmental Defense Fund, New York, N.Y.

This paper discusses the serious threat posed by acidic deposition to the high altitude ecosystems (particularly aquatic systems) in the intermountain region of the western United States. Given this situation, the authors attempt to determine the threshold for damage from acidic deposition for thcse ecosystems by using data from Scandinavian ecosystems, which are considered by the authors to be very similar to those in this intermountain region.

Most of the sulfur deposition in this region is the result of sulfur dioxide released by smelters. The authors conclude that the highly sensitive western intermountain watersheds will be significantly altered by total sulfur deposition rates in excess of $3 \mathrm{~kg} / \mathrm{ha} / \mathrm{yr}$. Long-term damage is likely if such deposition rates remain above $5 \mathrm{~kg} / \mathrm{ha} / \mathrm{yr}$. Total deposition of sulfur in this region has been observed to exceed the $5 \mathrm{~kg} / \mathrm{ha} / \mathrm{yr}$ threshold for damage.

The more serious concern is that even with a $30 \%$ reduction in current source emissions in the United States (as mandated by the pre-1990 Clean Air Act), the most sensitive ecosystems in this region will not be protected because of the planned increase in smelter capacity in Mexico. In addition, new capacity in the United States, particularly in the utility sector, will most likely result in deposition levels exceeding the threshold for damage in even moderately sensitive ecosystems. The results of this paper indicate that deposition loads will likely fall below the threshold value for these high-elevation ecosystems only if controls are enacted on all new industrial and utility plants in the United States and Mexico. Even if such a control policy is implemented, the location of the new plants and nitrogen loadings must be taken into account to determine the overall impact on these ecosystems. 


\section{BIBLIOGRAPHY*}

Agren, C. (1992). The UN ECE Convention on Long Range Transboundary Air Pollution. Submitted to the Third International NGO Strategy Seminar on Air Pollution, Goteborg, Sweden, April 10-12.

Alcamo, J., et al. (1987). Acidification in Europe: A Simulation Model for Evaluating Control Strutegies. Ambio 16:232-245.

Alcamo, J., R. Shaw, and L. Hordijk. (1990). The Rains Model of Acidification: Science and Strategies in Europe. Kluwer Academic Press, Boston.

Alm, H. (1989). Emissions Are Falling, but Is It Enough? Acid Magazine 8:5-6.

Amann, M., S. Batterman, and J.P. Hettelingh. (1987). Sulfur Emission Abatement Strategies Subject to Regional Deposition Target Levels in Europe. International Institute for Applied Systems Analysis, Laxenburg, Austria.

Amann, M. (1989). Using Critical Loads as the Basis for Abatement Strategies in Europe. Working paper submitted to the UN-ECE Task Force Meeting on Integrated Assessment Modeling, October.

Amann, M., et al. (1991). Economic Restructuring in Eastern Europe and Acid Rain Abatement Strategies. Working Paper for the International Institute for Applied Systems Analysis, Laxenburg, Austria, August.

Aniansson, B. (1987). Critical Loads - Painful Decisions Ahead. Acid Magazine 1:12-15.

Barker, M., and T. Ashenden. (1993). Foliar Injury in Young Betula Pendula Roth., Salix Purpurea L., and Ilex Aquifolium L. Trees and in Propagated Taxus Baccata L. Shoots Exposed to Intermittent Fog at a Range of Acidities. Environmental Pollution 80:123-127.

*Batterman, S. (1989). Selection of Receptor Sites for Optimized Acid Rain Control Strategies. Journal of Environmental Engineering 115:1046-1058.

Batterman, S. (1992). Optimized Acid Rain Abatement Strategies Using Ecological Goals. Environmental Management 16:133-141.

Batterman, S., and M. Amann. (1991). Targeted Acid Rain Strategies Including Uncertainty. Journal of Environmental Management 32:57-72.

* This bibliography lists every document that is cited in the text as well as other sources. Items preceded by an asterisk $\left({ }^{*}\right)$ are summarized in Section 4. 
Brakke, D., and A. Henriksen (1989). Uncertainties in Using Empirical Steady-State Models to Estimate Critical Loads of Strong Acids to Lakes. In Regional Acidification Models: Geographic Extent and Time Development, J. Kamari, D.F. Brakke, A. Jenkins, S.A. Norton, and R.F. Wright (editors), Springer-Verlag, Berlin, Germany, pp. 45-54.

*Bull, K. (1991). The Critical Loads/Levels Approach to Gaseous Pollutant Emission Control. Environmental Pollution 69:105-123.

Bull, K. (1992). An Introduction to Critical Loads. Environmental Pollution 77:173-176.

Chadwick, M. (1990). Relative Sensitivity, Critical Loads, and Target Loads and Their Inclusion in Acidic Deposition Abatement Strategy Models. In Second Annual Workshop on Acid Rain and Emissions in Asia, W.K. Foell and D. Sharma (editors), Asian Institute of Technology, Bangkok, Thailand, pp. 75-106.

${ }^{*}$ Chadwick, M., and J. Kuylenstierna (1989). Critical Loads and Critical Levels for the Effects of Sulphur and Nitrogen Compounds. Stockholm Environment Institute at York, University of York, York, U.K.

Chadwick, M., and M. Hutton (1991). Acid Depositions in Europe: Environmental Effects, Control Strategies, Policy Options. Stockholm Environmental Institute, Information Press, Oxford.

Crocker, T.D., and J. Regens (1985). Acid Deposition Control, A Benefit-Cost Analysis: Its Prospects and Limits. Environmental Science and Technology 19:112-116.

*Crocker, T.D., and B.A. Forster (1981). Decision Problems in the Control of Acid Precipitation: Nonconvexities and Irreversibilities. Journal of the Air Pollution Control Association 31:31-37.

Derwent, R. (1989). Critical Loads Concept and Its Application with Novel Optimization Techniques to Environmental Acidification in Europe. In Environmental Models: Emissions and Consequences, J. Fenhann, H. Larsen, G. Mackenzie, and B. Rasmussen (editors), Elsevier Science Publishers B.V., Amsterdam, Netherlands, pp. 437-448.

Derwent, R., and R. Wilson (1992). Acidification Research: Evaluation and Policy Applications, a United Kingdom Policy Response. Acidification Research, Evaluation and Policy, T. Schneider (editor), Elsevier Science Publishers B.V., Amsterdam, Netherlands, pp. 253-256.

De Vries, W., and H.D. Gregor (1991). Critical Loads and Critical Levels for the Environmental Effects of Air Pollutants. In Acid Depositions in Europe, M.J. Chadwick and M. Hutton (editors), Stockholm Environment Institute, Stockholm, Sweden, pp. 171-216. 
De Vries, W., and J. Kros (1991). Assessment of Critical Loads and the Impact of Deposition Scenarios by Steady-State and Dynamic Soil Acidification Models. In Acidification Research in the Netherlands: Final Report of the Dutch Priority Programme on Acidification, G. Heij, and T. Schneider (editors), Elsevier Science Publishers B.V., Amsterdam, Netherlands, pp. 569-624.

De Vries, W., et al. (1992). Critical Loads for Dutch Forest Soils. In Acidification Research, Evaluation and Policy, T. Schneider (editors), Elsevier Science Publishers, B.V., Amsterdam, Netherlands, pp. 307-318.

Eilers, J., et al. (1983). Hydrological Control of Lake Susceptibility to Acidification. Canadian Journal of Fisheries and Aquatic Science 40:1896-1904.

Ekman, H. (1986). The Limits to Nature's Tolerance. Acid Magazine 4:28-30.

Ellis, J.H. (1988). Acid Rain Control Strategies: Options Exist Despite Uncertainties. Environmental Science and Technology 22:1248-1255.

Ellis, J.H., et al. (1990). Deposition-Constrained Optimization Models for Acid Rain Control: Quantitative Links Between Critical Loads and Abatement Strategies. Presentation to the United States Critical Loads Program, November.

Evans, L., et al. (1981). Acidic Precipitation: Considerations for an Air Quality Standard. Water, Air, and Soil Pollution 16:469-509.

Forsius, M., J. Kamari, and M. Posch. (1992). Critical Loads for Finnish Lakes: Comparison of Three Steady-State Models. Environmental Pollution 77:185-193.

Gregor, H.D. (1988). Critical Levels for the Effects of Air Pollutants on Plants, Plant Communities, and Ecosystems. Federal Environmental Agency, Berlin, Germany.

Grennfelt, P. (1992). The Critical Levels for Ozone and the Necessary Reduction of the Emissions of Ozone Precursors. Submitted to the Third International NGO Strategy Seminar on Air Pollution, Goteborg, Sweden, April 10-12.

${ }^{*}$ Gringal, D.F. (1991). The Concept of Target and Critical Loads. Electric Power Research Institute, Palo Alto, Calif.

Haigh, N. (1989). New Tools for European Air Pollution Control. International Environmental Affairs 1:26-37.

Henriksen, A. and D.F. Brakke. (1988). Sulfate Deposition to Surface Waters. Environmental Science and Technology 22:8-14.

Hettelingh, J.P. (1990). Guidelines for Design of an Acid Rain Policy for Asia. In Second Annual Workshop on Acid Rain and Emissions in Asia, W.K. Foell and D. Sharma (editors), Asian Institute of Technology, Bangkok, Thailand, pp. 34-46. 
Hettelingh, J.P., R.J. Dowling, and P.A.M. de Smet (1991a). European Critical Loads Maps. In Mapping Critical Loads for Europe, CCE Technical Report No. 1, RIVM, Bilthoven, Netherlands, pp. 5-30.

Hettelingh, J.P., et al. (1991b). Methods and Data. In Mapping Critical Loads for Europe, CCE Technical Report No. 1, RIVM, Bilthoven, Netherlands, pp. 31-48.

Hettelingh, J.P., R.J. Downing, and P.A.M. de Smet (1992a). The Critical Loads Concept for the Control of Acidification. In Acidification Research, Evaluation and Policy, T. Schneider (editor), Elsevier Science Publishers B.V., Amsterdam, Netherlands, pp. 161-174.

*Hettelingh, J.P., R. Gardner, and L. Hordijk (1992b). A Statistical Approach to the Regional Use of Critical Loads. Environmental Pollution 77:177-183.

Hicks, B., et al. (1993). A National Critical Loads Framework for Atmospheric Deposition Effects Assessment: III. Deposition Characterization. Environmental Management 17:343-353.

Holdren, G., et al. (1990). Critical Loads Estimates: Effects of Major Assumptions. Presentation to the United States Critical Loads Program, November.

Holdren, G., et al. (1993). A National Critical Loads Framework for Atmospheric Deposition Effects Assessment: IV. Model Selection, Applications, and Critical Loads Mapping. Environmental Management 17:355-363.

Holdren, G., et al. (1993). Comparison of Selected Critical Loads Estimation Approaches for Assessing the Effects of Sulfate Deposition on Lakes in the Northeastern United States. U.S. Environmental Protection Agency Technical Publication.

Holdren, G., et al. (1993). Sensitivity of Critical Load Estimates for Surface Waters to Model Selection and Regionalization Schemes. Journal of Environmental Quality 22:279-289.

Hunsaker, C., et al. (1993). A National Critical Loads Framework for Atmospheric Deposition Effects Assessment: II. Defining Assessment End Points, Indicators, and Functional Subregions. Environmental Mianagement 17:335-341.

Kamari, J. (1989). Sensitivity, Load, and Time: Aspects of Determining a Target Load for Lake Regions. In Regional Acidification Models: Geographic Extent and Time Development, J. Kamari, D.F. Brakke, A. Jenkins, S.A. Norton, and R.F. Wright (editors), Springer-Verlag, Berlin, Germany, pp. 55-65.

Kamari, J., et al. (1992). The Use of Critical Loads for the Assessment of Future Alternatives to Acidification. Ambio 21:377-386. 
Kamari, J., M. Forsius, and M. Posch (1993). Critical Loads of Sulfur and Nitrogen for Lakes II: Regional Extent and Variability in Finland. Water, Air, and Soil Pollution 66:77-96.

Kuylenstierna, J., and M. Chadwick (1988). The Relative Sensitivity of Ecosystems in Europe to the Indirect Effects of Acidic Deposition. Stockholm Environment Institute at York, York, U.K.

Langan, S., and M. Hornung (1992). An Application and Review of the Critical Load Concept to the Soils of Northern England. Environmental Pollution 77:205-210.

Lumme, E. (1992). Acidification Policy in Finland. In Acidification Research, Evaluation and Policy, T. Schneider (editor), Elsevier Science Publishers B.V., Amsterdam, Netherlands, pp. 185-189.

Memorandum of Intent (U.S./Canada Memorandum of Intent on Transboundary Air Pollution) (1983). Work Group I, Impact Assessment. Final Report, Supply and Services Canada, Ottawa, Ontario.

Milburn-Hopwood, S., and K. Puckett (1992). Canadian Acid Rain Policy. In Acidification Research, Evaluation and Policy, T. Schneider (editor), Elsevier Science Publishers B.V., Amsterdam, Netherlands, pp. 177-184.

Mill, W. (1992). Acidification Research Activities in Poland. In Acidification Research, Evaluation and Policy, T. Schneider (editor), Elsevier Science Publishers B.V., Amsterdam, Netherlands, pp. 301-306.

Molburg, J. (1993). The Utility Industry Response to Title IV: Generation Mix, Fuel Choice, Emissions, and Costs. Journal of the Air and Waste Management Association 43:180-186.

*Newcombe, C. (1993). Acid Deposition in Aquatic Ecosystems: Setting Limits Empirically. Environmental Management 9:277-288.

Nilsson, J. (1986). Critical Loads for Sulfur and Nitrogen. Report from a Nordic Working Group, Nordic Council of Ministers, Stockholm, Sweden.

Pallemaerts, M. (1988). The Politics of Acid Rain Control in Europe. Environment 30:42-44.

Persson, G. (1988). The Critical Loads Approach as a Policy Option to Reduce Transboundary Air Pollution. Paper submitted to the Conference on Air Pollution in Europe: Environmental Effects, Control Strategies, and Policy Options, Stockholm, Sweden, September 26-30.

Peterson, J., et al. (1990). Guidelines for Evaluating Air Pollution Impacts on Class I Wilderness Areas in the Pacific Northwest. Presented at a workshop held in Orcas Island, Washington, May. 
Posch, M., M. Forsius, and J. Kamari (1993). Critical Loads of Sulfur and Nitrogen for Lakes I: Model Description and Estimation of Uncertainty. Water, Air, and Soil Pollution 66:173-192.

Ringold, P., J.H. Ellis, and R. Holdren (1990). Evaluation of Differing Critical Loads Estimates in Terms of Quantitatively Linked Emission Control Strategies. Presentation to the United States Critical Loads Program, November.

RMCC (Federal/Provincial Research and Monitoring Coordinating Committee) (1986). Assessment of the State of Knowledge on the Long-Range Transport of Air Pollutants and Acid Deposition. Part 1. Executive Summary. Environment Canada, Downsview, Ontario.

RMCC (Federal/Provincial Research and Monitoring Coordinating Committee) (1990a). The 1990 Assessment Canadian Long-Range Transport of Air Pollutants and Acid Deposition Assessment Report: Part 1. Executive Summary. Environment Canada, Downsview, Ontario.

RMCC (Federal/Provincial Research and Monitoring Coordinating Committee) (1990b). The 1990 Canadian Long-Range Transport of Air Pollution and Acid Deposition Assessment Report: Part 4. Aquatic Effects. Environment Canada, Downsview, Ontario.

Sand, P. (1987). Air Pollution in Europe: International Policy Responses. Environment 29:16-20, 28-29.

Shaffer, P., et al. (1991). Estimating Critical Loads of Sulfate to Surface Waters in the Northeastern United States: A Comparative Assessment of Three Procedures for Estimating Critical Loads of Sulfate for Lakes. Environmental Research Laboratory, Corvallis, Office of Research and Development, U.S. Environmental Protection Agency, Corvallis, Oregon.

Scharer, B. (1992). Acidification Policy-Control of Acidifying Emissions in Germany. In Acidification Research, Evaluation and Policy, T. Schneider (editor), Elsevier Science Publishers B.V., Amsterdam, Netherlands, pp. 191-201.

Shaw, R. (1986a). Optimization of Emission Reductions to Reduce Atmospheric Sulfur Deposition in Europe: An Examination of a Methodology. Water, Air, and Soil Pollution 30:879-884.

Shaw, R. (1986b). A Proposed Strategy for Reducing Sulphate Deposition in North America-II. Methodology for Minimizing Costs. Atmospheric Environment 20:201-206. 
Shaw, R., and M. Amann (1989). Effect of Uncertainty in Source-Receptor Relationships on Transboundary Air Pollution Control Strategies. In Environmental Models: Emissions and Consequences, J. Fenhann, H. Larsen, G. Mackenzie, and B. Rasmussen (editors), Elsevier Science Publishers B.V., Amsterdam, Netherlands, pp. 415-425.

Schulze, E., et al. (1989). Critical Loads for Nitrogen Deposition on Forest Ecosystems. Water, Air and Soil Pollution 48:451-456.

Skeffington, R., and E. Wilson (1988). Excess Nitrogen Deposition: Issues for Consideration. Environmental Pollution 54:154-184.

Smith, F. (1992). Emission Reductions to Meet Deposition Criteria. Atmospheric Environment 26A:609-624.

Smith, C., M. Cresser, and R. Mitchell (1993). Sensitivity to Acid Deposition of Dystrophic Peat in Great Britain. Ambio 22:22-26.

*Streets, D., D. Hanson, and L. Carter (1984). Targeted Strategies for Control of Acidic Deposition. Journal of the Air Pollution Control Association 34:1187-1197.

Streets, D., et al. (1985). Climatological Variability: Effect on Strategies to Reduce Acid Deposition. Environmental Science and Technology 19:887-893.

Strickland, T., et al. (1993). A National Critical Loads Framework for Atmospheric Deposition Effects Assessment: I. Method Summary. Environmental Management 17:329-334.

Styver, P., and M. Stein. (1992). Acid Deposition Models for Detecting the Effect of Changes in Emissions: An Exploratory Investigation Utilizing Meteorological Variables. Atmospheric Environment 26A:3019-3028.

Sverdrup, H. (1992). Methods for Determining and Mapping Critical Loads for Acidity. Submitted to the Third International NGO Strategy Seminar on Air Pollution, Goteborg, Sweden, April 10-12, 1992.

Sverdrup, H., et al. (1992). Critical Loads and Steady-State Chemistry for Streams in the State of Maryland. Environmental Pollution 77:195-203.

Swedish NGO Secretariat on Acid Rain. (1992). Critical Loads for Air Pollutants. Report of the Third International NGO Strategy Seminar on Air Pollution, Goteborg, Sweden, April 10-12.

Swedish NG:O Secretariat on Acid Rain. (1993). Critical Loads: The Limits of Tolerance. Acid News 1:I-IV. 
Tickle, A. (1992). Critical Loads for Nitrogen and Their Use in National and International NGO Campaigning. Submitted to the Third International NGO Strategy Seminar on Air Pollution, Goteborg, Sweden, April 10-12.

UN-ECE (1991). Mapping Critical Loads for Europe. Convention on Long-Range Transboundary Air Pollution, CCE Technical Report No. 1.

Utility Environment Report (1993). N.Y. Utilities, Environmentalists Sue EPA to Alter 1990 Clean Air Act Rules. Utility Environment Report, March 19, pp. 1-2.

Warfvinge, P., et al. (1992). The Use of Dynamic Models to Set Target Loads. Ambio 21:369-376.

Waters, D., and P. Whitehead (1992). Global Environmental Change: Implications for Acid Deposition Research. In Acidification Research, Evaluation and Policy, T. Schneider (editor), Elsevier Science Publishers B.V., Amsterdam, Netherlands, pp. 45-53.

*Young, J., and R. Shaw (1986). A Proposed Strategy for Reducing Sulphate Deposition in North America-I. Methodology for Minimizing Sulphur Removal. Atmospheric Environment 20:189-199.

*Yuhnke, R., and M. Oppenheimer (1984). Safeguarding Acid-Sensitive Waters in the Intermountain West: A Sulfur Pollution Strategy for Preventing Damage in the Intermountain Air Shed. Environmental Defense Fund, New York, N.Y. 

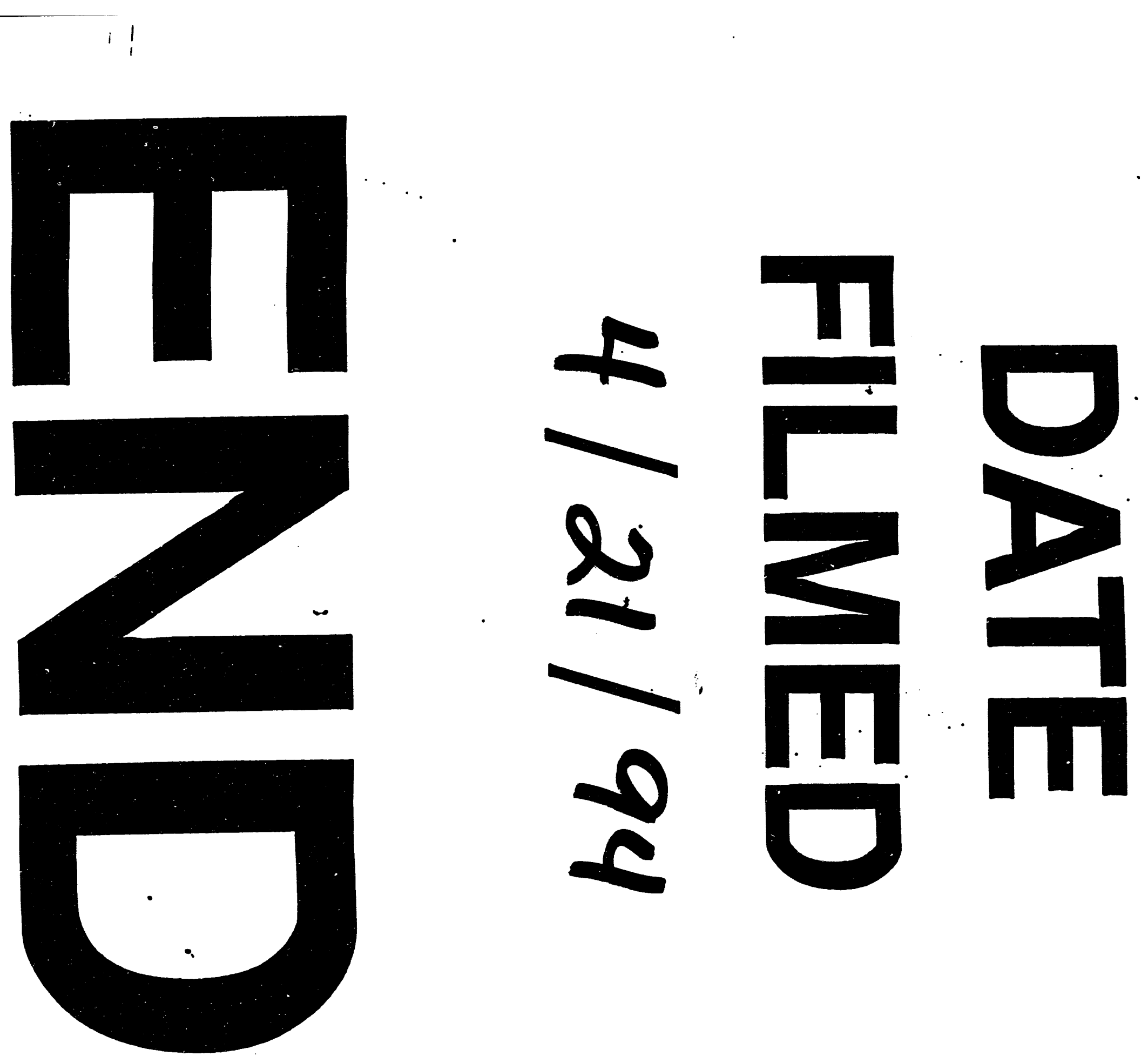


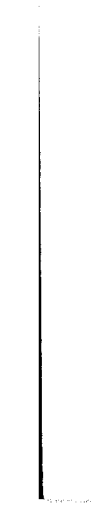

